\title{
Changes in the top management team: performance implications of altering team composition
}

Citation for published version (APA):

Glunk, U., \& Heijltjes, M. G. (2003). Changes in the top management team: performance implications of altering team composition. METEOR, Maastricht University School of Business and Economics. METEOR Research Memorandum No. 050 https://doi.org/10.26481/umamet.2003050

Document status and date:

Published: 01/01/2003

DOI:

10.26481/umamet.2003050

Document Version:

Publisher's PDF, also known as Version of record

\section{Please check the document version of this publication:}

- A submitted manuscript is the version of the article upon submission and before peer-review. There can be important differences between the submitted version and the official published version of record.

People interested in the research are advised to contact the author for the final version of the publication, or visit the DOI to the publisher's website.

- The final author version and the galley proof are versions of the publication after peer review.

- The final published version features the final layout of the paper including the volume, issue and page numbers.

Link to publication

\footnotetext{
General rights rights.

- You may freely distribute the URL identifying the publication in the public portal. please follow below link for the End User Agreement:

www.umlib.nl/taverne-license

Take down policy

If you believe that this document breaches copyright please contact us at:

repository@maastrichtuniversity.nl

providing details and we will investigate your claim.
}

Copyright and moral rights for the publications made accessible in the public portal are retained by the authors and/or other copyright owners and it is a condition of accessing publications that users recognise and abide by the legal requirements associated with these

- Users may download and print one copy of any publication from the public portal for the purpose of private study or research.

- You may not further distribute the material or use it for any profit-making activity or commercial gain

If the publication is distributed under the terms of Article $25 \mathrm{fa}$ of the Dutch Copyright Act, indicated by the "Taverne" license above, 


\section{CHANGES IN THE TOP MANAGEMENT TEAM: Performance implications of altering team composition}

\section{URSULA GLUNK}

Universiteit Maastricht, Faculty of Economics and Business Administration, Department of Organization and Strategy, P.O.Box 616, 6200 Maastricht, The Netherlands

$$
\begin{gathered}
\text { Telephone: }+31.43 .3883812 \\
\text { Fax: }+31.43 .3884877 \\
\text { E-mail: U.Glunk@os.unimaas.nl }
\end{gathered}
$$

\section{MARIËLLE G. HEIJLTJES}

Universiteit Maastricht, Faculty of Economics and Business Administration, Department of Organization and Strategy, P.O.Box 616, 6200 Maastricht, The Netherlands

$$
\begin{gathered}
\text { Telephone: }+31.43 .3883812 \\
\text { Fax: }+31.43 .3884877
\end{gathered}
$$

E-mail:M.Heijltjes@os.unimaas.nl 


\title{
CHANGES IN THE TOP MANAGEMENT TEAM: \\ Performance implications of altering team composition
}

\begin{abstract}
This study focuses on the performance implications of changes in the top management team using an eleven-year period longitudinal research design with a sample of 45 of the largest corporations in the Netherlands. The central argument of this paper builds on the idea that exits and entries of top management team members have a significant impact on subsequent firm performance due to the resulting changes in the composition of the team. Two aspects of team composition - organizational tenure and age - are examined in more detail. Specifically it is argued that changes in the top team which lead to higher degrees of dissimilarity between members of the team on the two aspects examined, will have a negative effect on performance. Results indicate that exits and entries indeed have performance implications in the years following the change. These performance effects can, however, not be attributed to increasing age or tenure dissimilarity.
\end{abstract}




\section{INTRODUCTION}

Changes in top management teams are becoming more and more frequent due to poor organizational performance, mergers and acquisitions, and strategic reorientations (Leonard, 2001). This trend, in a way, reflects a desire to influence the performance of the firm by means of altering the composition of the top management team. According to upper echelon theory, this might be a feasible strategy since research has demonstrated a link between attributes of top management team members and firm performance (Hambrick and Mason, 1984). Specifically, upper echelon theory argues that individual attributes influence the preferences and attitudes of top team members, as well as the resulting team dynamics. In turn, these affect the strategic choices managers make, and therefore, organizational outcomes (Smith et al., 1994; Finkelstein and Hambrick, 1996; Tsui and Gutek, 1999).

In light of this, two questions emerge that we will focus on in this paper. The first one deals with performance effects of the changes in the top team itself. In other words, are changes in the top management team in general a curse or a blessing? The second question builds on the first one by specifically exploring the nature of the changes in the top team. After all, exits and entries change the mix of visible (e.g. age) and invisible (e.g. tenure) attributes of the top team members. Following upper echelon theory, this will have performance implications. Whether this effect will be positive or negative depends on the degree of instability and social costs involved in the change.

By exploring these two questions we will add to the existing body of research in two respects. First, while the majority of literature focuses on performance effects of CEO changes only (e.g., Kesner and Dalton, 1994; Wiersema and Bantel, 1992), we will consider changes in the entire top management team. Second, we will determine the changes in team composition that result from executive exits and entries and analyze the effects of these compositional changes on subsequent firm performance.

\section{CHANGES IN THE TOP TEAM AND SUBSEQUENT PERFORMANCE}

The argumentation of the present study draws from CEO succession research and upper echelon theory. Research on CEO succession can be traced back to the sixties and has since developed into an extensive research area. However, despite the large number of studies on the succession-performance relationship, no consistent model of performance consequences 
and associated contingencies has yet emerged (Shen and Canella, 2002). Basically, the results of these studies fit into three different theories of succession that each proposes a different relationship with post-succession performance (Kesner and Dalton, 1994; Kesner and Sebora, 1994).

The first theory is referred to as 'common sense' and is based on the assumption that a new CEO will be chosen who has the expertise and experience to enhance firm performance. Studies assuming that a CEO can be instrumental in breaking organizational inertia and initiating strategic change fit into this theoretical perspective (Gordon et al., 2000; Kesner and Dalton, 1994). The second so-called 'vicious circle theory' assumes just the opposite: successions have a disruptive effect on the organization in terms of increasing instability and ambiguity and will thus lead to lower firm performance. Since poor performance might have been the cause of the succession, the organization can end up in a downward spiral. The third theory, 'ritual scapegoating', suggests that there is no relationship between succession and performance and that succession events just serve as signals to stakeholders about potential changes within the organization. Examples of studies in line with this notion are those that investigate the relationship between succession and market reactions. The implication of this theory is that the CEO cannot, or only to a very small extent, influence the (accounting-based) performance of the organization.

Upper echelon theory broadened the research field by proposing that one has to look beyond the characteristics of the CEO alone and should also take the characteristics and functioning of other members of the top management team into account for understanding firm performance (Hambrick and Mason, 1984). The underlying assumption within upper echelon theory is that by looking at characteristics of the whole group of top-level managers, better predictions of organizational outcomes will be obtained (Finkelstein and Hambrick, 1996; Ancona, 1990). In the context of executive changes, this approach provides interesting avenues for research, as every entry and exit changes the composition of the team.

The few studies that investigated performance effects of changes in top management teams came to inconsistent results. For example, Virany, Tushman and Romanelli (1992) found that both CEO succession and executive team changes have a positive effect on performance. This result matches the 'common-sense' theory. Canella and Hambrick (1993) provide evidence for a negative performance effect when studying executive turnover in the specific context of acquisitions. This result more closely matches the notion that changes in the top management team have a potentially disruptive effect on performance. 
Our study argues that, next to looking at entries and exits as such, we also have to look at changes in team composition resulting from exits and entries in order to understand their performance effects. In the following, we will develop our hypotheses concerning 1) the effects of changes in the top management team as such and 2) whether these effects can be explained by the resulting changes in organizational tenure and age homogeneity within the top management team.

\section{HYPOTHESES}

The literature review on changes in top management teams clearly indicates that results with respect to the performance implications are still inconsistent. This leads our first hypothesis to be of a general nature.

Hypothesis 1: Changes in top management teams have an impact on subsequent performance

Changes in top management team composition can be due to exits of former members or entries of new members. When studying the effects of such changes in more depth, the characteristics of the entering and leaving members in relation to the characteristics of the incumbent members become important. Will the team become more similar or more dissimilar as a result of the change? And what will the performance effects of these changes be? These questions are closely linked to the homogeneity versus heterogeneity debate in upper echelon research. Searching there, however, does not generate easy answers since the conclusions on the relationship between top management team diversity and performance have been contradictory (Hambrick, Cho and Chen, 1996). Some studies conclude that homogeneity within the top management team is beneficial for performance; for example studies following the similarity/attraction paradigm (summarized in Williams and O'Reilly, 1998). These argue that the negative effects of turnover in terms of social costs may be lower when newcomers are relatively similar to incumbent members. In fact, the finding that people consciously and unconsciously prefer others who are similar to them is one of the most robust and reliable social psychological findings (Barsade et al., 2000, p. 805). Furthermore, similarity in demographic characteristics influences the type of information and knowledge within the group (Tsui and Gutek, 1999). More homogeneous groups will have similar information sources, insights and skills at their disposal, decreasing the risk of group conflict. However, there are also studies based on information and decision-making theory that 
propose that diverse groups make better decisions (Cox, 1994). The underlying rationale here is that "diversity enhances the breadth of perspectives, cognitive resources and overall problem-solving capacity" (Hambrick, Cho and Chen, 1996, p. 662; Barsade et al., 2001).

The present study does, however, not focus on the performance effects of team heterogeneity as such, but on changes in heterogeneity due to exits and entries. In order to analyze whether top management teams become more heterogeneous or homogeneous, the characteristics of the team before and after the change need to be compared. Since there might be different effects for the visible and non-visible characteristics of team members, we develop hypotheses for organizational tenure (invisible) as well as age (visible).

The argument for organizational tenure follows the research results with respect to insider/outsider effects of CEO succession in which it is argued that firms with insider CEOs tend to be more profitable than firms with outsider CEOs. Insider CEOs with longer organizational tenure benefit from knowing the organization's way of operating and thus have an existing social and political network (Shen and Cannella, 2002; Virany et al., 1992). They will thus be more similar to incumbent team members than outsiders. However, focusing on successor origin alone to explain effects of succession does not appear to be enough according to Friedman and Saul (1991). Next to successor origin they investigated the effects of CEO predecessor tenure on turnover of other executive members. Their findings suggest that predecessor tenure indeed matters. The study thus broadens the insider/outsider discussion by emphasizing the importance of organizational tenure of the predecessor as well as the successor. Although this topic has not yet been extensively studied at the team level, extending the evidence found at the CEO-level implies that there will be less disruption in the team when new members are rather similar to incumbent members in terms of organizational tenure. For example, when the incumbent top management team members each have a long organizational tenure, a newcomer entering the team with a similar organizational tenure will presumably ensure a relatively smooth transition since all members are aware of the company's way of operating, decision-making procedures, culture etc. However, when in this same situation a short-tenured newcomer enters, his/her way of working may deviate causing disruption of the traditional accepted patterns of values and behaviors, leading to declining performance. Although only for the relationship between heterogeneity in tenure and informal communication, Smith et al. (1994) support this line of reasoning. In their study they found a negative relationship between heterogeneity in tenure and informal communication. Hypothesis 2 summarizes these arguments for situations in which the composition of the top management team has been changed due to exits and entries. 
Hypothesis 2: An increase in tenure dissimilarity due to entries and exits in the top management team will have a negative impact on subsequent firm performance.

Hypothesis three builds on the ideas of social identity theory in which it is argued that people classify themselves and others in terms of social categories (e.g., age groups) and accentuate differences between and similarities within these categories (Turner and Onorato, 1999; Tajfel, 1978). Such categorization processes lead to the creation of in-groups and out-groups resulting in stereotyping, deteriorating communication, and decreased cooperation (Williams and O'Reilly, 1998). For changes in the top management team this implies that when the composition of the team becomes more dissimilar due to entries and exits, the in-group, outgroup phenomenon is more likely to incur, including the resulting negative impact on performance.

Research on the performance implications of age diversity in top management teams has provided mixed results (Richard and Shelor, 2002). However, studies in the tradition of social-identity theory predicted that age diversity, in isolation, has negative effects on the group process (Thomas and Ely, 1996). The resulting hypothesis in terms of increasing dissimilarity is summarized below.

Hypothesis 2: An increase in age dissimilarity due to entries and exits in the top management team will have a negative impact on subsequent firm performance.

The hypotheses and the resulting research model are summarized in Figure 1.

-------Insert Figure 1-------

\section{METHODS}

\section{Sample and Data Collection}

Our sample comprises data from the 45 largest MNCs in the Netherlands over an 11-year period (1990 to 2000). Starting from the top 50 firms on the Amsterdam Stock Exchange (in terms of total revenues of 1996), we excluded three bi-national firms (i.e., Shell, Unilever, Fortis), one Belgium firm (i.e., EVC) and one firm with insufficient data, from our sample in 
order to increase the accuracy of analysis. The resulting 45 companies in our sample are active in various industries, including among others chemicals, publishing \& printing, insurances, construction, and transportation. Within the observation period, their average sales amounted to 4.3 billion $€$ and they employed 29,000 employees. Given that we chose the largest listed firms, the sample is not representative of all 165 firms listed on the Amsterdam Stock Exchange.

\section{Dependent Measure}

Firm Performance. Firm performance was measured in terms of yearly return on assets (ROA), which is the most common performance measure in CEO turnover and succession research (Gordon et al., 2002; Guthrie and Datta, 1998; Kesner and Dalton, 1994; Shen \& Cannella, 2002; Tushman \& Rosenkopf, 1996; Virany et al., 1992; Zajac, 1990). We determined the relative change in ROA following top management team changes by subtracting ROA in the year when the change occurred ( $t 0$ ) from ROA in $t+x$ (see also Tushman \& Rosenkopf, 1996; Virany et al., 1992). Though change in ROA is known to be more difficult to predict than absolute ROA, this measure enables us to benchmark postchange ROA against ROA at the time the executive change occurred. While prior studies have studied the effects of top management team changes two years after the event (Tushman \& Rosenkopf, 1996; Virany et al., 1992), we measured the relative change in ROA one, two, and three years after the event in order to explore the strength of performance effects over time.

\section{Independent Measures}

The Dutch corporate governance structure is based on a two-tier system in which the Management Board and the Supervisory Board are separate entities. As the present study examines changes at the top management-team level, our data collection focused exclusively on executives in the Management Board.

Proportion of change in the top management team. For measuring changes in the top management team, entries and exits were considered independently as not every exit automatically leads to an entry or vice versa. We recorded the number of exit and entry events per team and year and calculated the proportion of entries and exits by dividing the number of exits (or entries) per year by the total number of top management team members at the beginning of that year (see also Tushman and Rosenkopf, 1996; Virany et al.,1992).

Changes in age and organizational tenure dissimilarity. Dissimilarity of age and organizational tenure was measured by calculating the standard deviation of these variables 
per team and year (see also Hambrick, Cho and Chen, 1996). Whether dissimilarity in age and organizational tenure increased or decreased due to entries or exits was determined by calculating the difference in the spread of age and tenure at the beginning and at the end of each year. A positive value represents an increase in similarity, a negative value an increase in dissimilarity.

\section{Control Variables}

In order to have a rough sector control in our multi-industry sample, we added a dummy variable distinguishing between non-manufacturing (coded as 0) and manufacturing firms (coded as 1). We controlled for firm size by using the natural logarithmic transformation of net sales in $€$ per firm and year as firm size may influence both, changes in the management board and performance. Furthermore, we controlled for firm performance prior to the entry or exit events, as performance effects might be different for firms with higher or lower performance rates prior to the executive change (Kesner and Dalton, 1994; Murphy and Zimmerman, 1993). In order to capture such effects, we measured ROA change prior to the top management team change by subtracting ROA at the end of $t-1$ from ROA $t-2$.

\section{Analysis}

Hypotheses 1-3 were analyzed by using random-effect regression models in a pooled crosssectional time series (see Greene, 2003). We analyzed 495 year-firm observations where the data set contains a separate entry for each firm $(\mathrm{N}=45)$ and year $(\mathrm{N}=11)$. It should be noted that the number of year-firm observations is not identical for the different time-dependent performance measures. Taking the control variable prior performance change into account, we can link the dependent variable ROA change in $\mathrm{t}+1$ to entries or exits between 1992 and 1999 $(\mathrm{N}=360)$, ROA change in $\mathrm{t}+2$ to entries/exits between 1992 and $1998(\mathrm{~N}=315)$, and ROA change in $\mathrm{t}+3$ to entries/exits between 1992 and $1997(\mathrm{~N}=270)$.

\section{RESULTS}

In total, 425 executives populated the top management teams of the 45 MNCs we studied between 1990 and 2000. Of the 170 top executives who were part of the top management team in 1990, only 44 were still in function in 2000. During our 11-year observation period, 227 exits (yearly average for the 45 firms: 20.6) and 250 entries (yearly average: 22.7) took place. On average, the top management teams had 4.2 members, with a minimum of two and 
a maximum of thirteen members. The exit proportion in the Dutch top management teams increased considerably between 1990 and 2000. While in 1990 only $8 \%$ of the executives left the teams, the exit proportion in 1999 was $13 \%$, in 2000 even $35 \%$. In the same period, entry proportions did not change as drastically, increasing only from $11 \%$ to $15 \%$.

-------Insert Table 1-------

Table 1 reports the means, standard deviations, and correlation coefficients of the variables used in our study. Here, we see that executive changes are more likely in poorly performing firms. Exit as well as entry proportions are higher in firms that experienced a decrease in ROA in the previous year (prior ROA change). Moreover, we see that the higher the proportion of exits in a given year, the more ROA increases in the following two years (ROA change $\mathrm{t} 1$, ROA change $\mathrm{t} 2$ ). Concerning our age and tenure homogeneity, we see a rather obvious link with entry proportion. The more entries take place in a given year, the more the similarity in age and organizational tenure decreases.

-------Insert Table 2-------

Table 2 shows the results of our test of hypotheses. Looking at the control variables first, we find that prior ROA change is negatively linked to subsequent ROA change; indicating that a performance decrease is usually followed by an increase (and vice versa). Sector and firm size show no effect on performance.

In line with Hypothesis 1, in we find that changes in the top management team do affect subsequent performance. A high proportion of exits in Dutch top management teams were found to lead to a performance increase in the two following years. At the same time, entries do have a rather negative effect on performance (although not always significant). Concerning ROA change in $\mathrm{t} 3$, we see again that exits and entries have opposing signs, here however, neither effect is significant.

Hypotheses 2 and 3 predicted that a higher degree of dissimilarity in organizational tenure and age due to exits and exits would have a negative effect on subsequent performance. No link at all could be found between an increase in dissimilarity and subsequent performance. From these results we have to conclude that Hypotheses 2 and 3 were not confirmed. 


\section{DISCUSSION AND CONCLUSION}

Exits and entries at the top level of the firm are noteworthy events, especially as they are surrounded by a lot of diverging expectations. Our data showed, that in Dutch MNCs the number of exits increased drastically during the 1990s, indicating more and more turbulence at the top. But what are the effects of such turbulence? Do the newcomers guarantee the desired performance improvement as assumed by the so-called common-sense approach? Or does a high degree of turbulence at the top add to a firm's instability and thus impact firm performance in a negative way, as suggested by the vicious-circle approach? Or, finally, do changes at the top basically not matter at all? Our longitudinal study of compositional changes in Dutch top management teams aimed at making a contribution to answering these questions.

Our results show, that when studying top management team changes, we have to distinguish between exits and entries. We found that the turnover of executives had positive effects on performance in the following two years. These findings follow the assumptions of the common sense approach in which the departure of top managers is associated with a change in strategic direction of the firm, the overcoming of resistance to change and the breaking of existing routines (Gordon, et. al. 2000, Virany et. al. 1992). Also studies focusing on the internal monitoring aspect of top management exits are in line with our results. These argue that top managers exit a top management team when they do not perform according to a pre-set standard. As a result, firm performance increases after their departure (Denis \& Denis, 1995).

The entrance of new executives to the top management team, however, had slightly negative performance effects. One potential explanation for this result could be found in the social cost argument. Integrating new members to the team is costly in terms of time and effort. The more new executives enter the team, the more care is needed for smoothening social processes, for guaranteeing knowledge transfer and finding new mutually agreed upon ways of operating. It was therefore somewhat surprising that our study showed that it does not matter for performance whether the dissimilarity in age or tenure in the team increases due to executive changes, since following the reasoning in the similarity-attraction paradigm and the logic of social categorization (Williams \& O'Reilly, 1998), we would indeed expect an effect. The positive effect of exits and the slightly negative effects of entries, however, were found independent of an increase in dissimilarity in age and tenure.

Summarizing, although our results show that changes in the top management team have an impact on performance in the sense that executive exits are more advantageous than 
executive entries, it remains unclear what the nature of the changes in team composition is. This provides several avenues for future research. For one, it might be fruitful to distinguish between different types of exits and entries. With respect to exit the distinction between voluntary and involuntary might be useful, while with respect to entries the type of entrants and succession context (Shen \& Cannella, 2002) might be interesting. Furthermore, studying other more task-related compositional indicators, such as functional backgrounds or industry experience of newcomers, might provide further insights. One major limitation of our study is its focus on a single performance indicator. We hope that future research is able to compare the effects of changes at the top on several performance measures. In particular a division between accounting-based measures and market-based measures might provide further insights into the reactions of shareholders to changes in top management teams. Overall, we hope that our study will inspire both managers and researchers who are puzzled by the effects of compositional changes at the top. 


\section{REFERENCES}

Ancona, D. 1990. Top management teams: Preparing for the revolution. In J. Carroll (Ed.), Applied Social Psychology and organizational settings: 99-128. New York: Earlbaum.

Bantel, K.A., Jackson, S.E. 1989. Top management and innovations in banking. Strategic Management Journal, 10: 107-129.

Barsade, S.G., Ward, A.J., Turner, J.D.F., Sonnenfeld, J.A., 2000. To your heart's content: a model of affective diversity in top management teams. Administrative Science Quarterly, 45, 802-836.

Brewster, C. 1993. Developing a 'European' Model of Human Resource Management. The International Journal of Human Resource Management, 4: 765-783.

Cannella, A.A., Hambrick, D.C. 1993. Effects of executive departures on the performance of acquired firms. Strategic Management Journal, 14: 137-152.

Cannella, A.A., Lubatkin, M. 1993. Succession as a sociopolitical process: Internal impediments to outsider selection. Academy of Management Journal, 36: 763-793.

Chaganti, R., Sambharya, R. 1987. Research notes and communications: Strategic orientation and characteristics of upper management. Strategic Management Journal, 8: 393-401.

Cox, T. 1994. Cultural diversity in organizations: theory, research, and practice, San Francisco: Berrett-Koehler.

Dalton, D.R. \& Kesner, I.F. 1985. Organizational performance as an antecedent of inside/outside chief executive succession: an empirical research. Academy of Management Journal, 28: 749-762.

Dalton, D.R., Kesner, I.F. 1983. Inside/outside succession and organizational size: The pragmatics of executive replacement. Academy of Management Journal, 26: 736-742.

Datta, D.K., Guthrie, J.P. 1994. Executive succession: Organizational antecedents of CEO characteristics. Strategic Management Journal, 15: 569-579.

Denis, D.J., Denis, D.K. 1995. Performance changes following top management dismissals, Journal of Finance, L:4, 1029 - 1057.

Finkelstein, S., Hambrick, D.C. 1996. Strategic leadership: top executives and their effects on organizations, New York: West.

Friedman, S.D., Saul. K. 1991. A leader's wake: organization member reactions to CEO succession. Journal of Management, 17.3: 619-642. 
Glunk, U., Heijltjes, M.G., Olie, R. 2001. Design characteristics and functioning of top management teams in Europe. European Management Journal. 19 : 291-300.

Gordon, S.S., Stewart, W.H., Sweo, R., \& Luker, W.A. 2000. Convergence versus strategic reorientation: the antecedents of fast-paced organizational change. Journal of Management, 26: 911-945.

Greene, W.H. 2003. Econometric analysis. Upper Saddle River: Prentice Hall.

Grusky, O. 1963. Managerial succession and organizational effectiveness. American Journal of Sociology, 69:21-31.

Guthrie J.P. \& Datta, D.K. 1998. Corporate strategy, executive selection, and firm perfomance. Human Resource Management, 37: 101-116.

Hambrick, D.C., Cannella, A.A. Jr. 1993. Relative standing: a framework for understanding departures of acquired executives. Academy of Management Journal, 36:733-762.

Hambrick, D.C., Cho, T.S., Chen M-J. 1996. The influence of top management team heterogeneity on firms' competitive moves. Administrative Science Quarterly, 41: 659-684.

Hambrick, D.C., Mason, P.A. 1984. Upper echelons: the organization as a reflection of its top managers. Academy of Management Review, 9:193-206.

Heijltjes, M.G., Van Witteloostuijn, A., Sorge, A. 1996. Human resource management in relation to generic strategies: a comparison of chemical and food and drink companies in the Netherlands and Great Britain. International Journal of Human Resource Management, 7.2: $383-412$.

Hofstede, G. (1991), Cultures and Organizations: Software of the Mind, Mc Graw-Hill, London.

Jackson, S.E., Brett, J.F., Sessa, V.I., Cooper, D.M., Julin, J.A., Peyronnin, K. 1991. Some differences make a difference: individual dissimilarity and group heterogeneity as correlates of recruitment, promotions, and turnover. Journal of Applied Psychology, 76: 675-689.

Kesner, I.F., \& Dalton, D.R. 1994. Top management turnover and CEO succession: an investigation of the effects of turnover on performance. Journal of Management Studies, 31: 701-713.

Kesner, I.F., Sebora, T.C. 1994. Executive succession: Past, Present \& Future, Journal of Management, 20.2: 327-372.

Leonard, B. 2001. Turnover at the top. HR Magazine, May: 46-52. 
Lane, Ch. 1992. European business systems: Britain and Germany compared. In R.D. Whitley (Ed.), European Business Systems: Firms and markets in their national contexts. London: Sage.

Murphy, K.J., Zimmerman, J.L.. 1993. Financial performance surrounding CEO turnover. Journal of Accounting and Economics. 16: 273-315.

Olie, R.L. 1996. European transnational mergers. Unpublished doctoral dissertation. Maastricht: Universiteit Maastricht.

Puffer, S.M., Weintrop, J.B. 1991. Corporate performance and CEO turnover: the role of performance expectations. Administrative Science Quarterly, 36: 1-19.

Richard, O.C., Shelor, R.M. 2002. Linking top management team age heterogeneity to firm performance: juxtaposing mid-range theories. International Journal of Human Resource Management, 13. 958-974.

Shen, W., Cannella, A.A. Jr. 2002. Revisiting the performance consequences of CEO succession: the impacts of successor type, postsuccession senior executive turnover, and departing CEO tenure. Academy of Management Journal, 45: 717-733.

Smith, K.G., Smith, K. A., Olian, J. D., O’Bannon, D.P. \& J.A. Scully (1994). Top management team demography and process. The role of social integration and communication. Administrative Science Quarterly, 39: 412-438.

Sorge, A. 1991. Strategic fit and the societal effect: Interpreting cross-national comparisons of technology, organization and human resources. Organization Studies, 12: 161-190.

Tajfel, H. 1978. Social categorization, social identity and social comparison. In Differentiation between Social Groups, Tajfel, H. (eds), Academic Press: London, 6176.

Thomas, D.A. Ely, R.J. 1996.Making differences matter: a new paradigm for management diversity (diversity in the workplace). Harvard Business Review, 74: 79-91

Tsui, A.S., Gutek, B.A. 1999. Demographic difference in organizations: current research and future directions. Lexington Press: Lanham, MD.

Turner, J.C., Onorato, R.S. 1999. Social identity, personality and the self-concept: A selfcategorization perspective. In The Psychology of the Social Self, Tyler, T.R., Kramer, R.M., and John, O.P. (eds) Lawrence Erlbaum Associates: Mahwah, 11-47.

Tushman, M.L., Rosenkopf, L. 1996. Executive succession, strategic reorientation and performance growth: a longitudinal study in the US Cement Industry. Management Science, 42: 939-953. 
Virany, B., Tushman, M.L., Romanelli, E. 1992. Executive succession and organization outcomes in turbulent environments: an organization learning approach. Organization Science, 3: 72-91.

Wiersema, M.F., Bantel, K.A. 1992. Top management demography and corporate strategic change. Academy of Management Journal, 35:91-121.

Williams, K.Y., O’Reilly C.A.III. 1998. Demography and Diversity in organizations: a review of 40 years of research. In: Research in Organizational Behavior, vol. 20, Staw. B., Sutton, R. (eds), JAI Press: Greenwich, CT. 182-203.

Williams, K., O'Reilly, C. 1997. The complexity of diversity: a review of forty years of research. In: Research on Managing in Groups and Teams. Gruenfeld, D. and Neale, M. (eds). Vol 1. Jai Press: Greenwich, CT.

Whitley, R. 1992. The Comparative Analysis of Business Systems: Societies, Firms, Markets: The Social Structuring of Business Systems, in: European Business Systems: Firms and Markets in their National Context, Whitley, R. (ed), Sage Publications: London.

Zajac, E.J. 1990. CEO selection, succession, compensation, and firm performance: a theoretical integration and empirical analysis. Strategic Management Journal, 11: 313 33 
TABLE 1

Means, Standard Deviations and Correlations

\begin{tabular}{|c|c|c|c|c|c|c|c|c|c|c|c|c|}
\hline & Mean & SD & 1. & 2. & 3. & 4. & 5 . & 6. & 7. & 8. & 9. & 10. \\
\hline 1. ROA change $t 1$ & 0.21 & 4.45 & 1.0 & & & & & & & & & \\
\hline 2. ROA change $\mathrm{t} 2$ & 0.30 & 5.36 & $.60 * * *$ & 1.0 & & & & & & & & \\
\hline 3. ROA change $t 3$ & 0.56 & 5.29 & $.37 * * *$ & $61 * * *$ & 1.0 & & & & & & & \\
\hline 4. Exit proportion & 0.10 & 0.18 & $.16^{* * *}$ & $.12 *$ & 04 & 1.0 & & & & & & \\
\hline 5. Entry prop. & 0.13 & 0.24 & .02 & -.01 & .05 & $.27 * * *$ & 1.0 & & & & & \\
\hline $\begin{array}{l}\text { 6. Change in age } \\
\text { homogeneity }\end{array}$ & -0.02 & 1.32 & -.03 & -.02 & 07 & .04 & -.03 & 1.0 & & & & \\
\hline $\begin{array}{l}\text { 7. Change in org. } \\
\text { tenure homog. }\end{array}$ & -0.11 & 3.25 & -.03 & -.05 & $-.21 * * *$ & $-.12 *$ & -.08 & .06 & 1.0 & & & \\
\hline 8. Sector & 0.55 & 0.49 & .01 & 05 & 03 & .04 & .03 & -.01 & -.00 & 1.0 & & \\
\hline 9. Net sales $(\ln )$ & 14.45 & 1.20 & -.05 & -.07 & 03 & $.17 * * *$ & $.10 *$ & .04 & -.02 & $-.22 * * *$ & 1.0 & \\
\hline $\begin{array}{l}\text { 10. Prior ROA } \\
\text { change }\end{array}$ & 0.04 & 4.03 & $-.12 *$ & $-.15 *$ & $-.15 *$ & $-.14 * *$ & $-.10 *$ & -.01 & .01 & .02 & -.03 & 1.0 \\
\hline
\end{tabular}




\section{TABLE 2}

GLS Regression Models: Changes in Team Homogeneity

\begin{tabular}{|c|c|c|c|c|c|c|c|c|c|}
\hline & Model 1 & Model 2 & Model 3 & Model 4 & Model 5 & Model 6 & Model 7 & Model 8 & Model 9 \\
\hline Variables & $\begin{array}{c}\text { ROA } \\
\text { change t1 }\end{array}$ & $\begin{array}{c}\text { ROA } \\
\text { change t2 }\end{array}$ & $\begin{array}{c}\text { ROA } \\
\text { change t3 }\end{array}$ & $\begin{array}{c}\text { ROA } \\
\text { change t1 }\end{array}$ & $\begin{array}{c}\text { ROA } \\
\text { change t2 }\end{array}$ & $\begin{array}{c}\text { ROA } \\
\text { change } \mathrm{t} 3\end{array}$ & $\begin{array}{c}\text { ROA } \\
\text { change t1 }\end{array}$ & $\begin{array}{c}\text { ROA } \\
\text { change t2 }\end{array}$ & $\begin{array}{c}\text { ROA } \\
\text { change t3 }\end{array}$ \\
\hline Sector & .06 & .31 & .38 & -.01 & .46 & .90 & .01 & .29 & .56 \\
\hline Net sales $(\ln )$ t0 & -.22 & -.26 & .15 & -.16 & -.24 & .06 & -.24 & -.29 & .21 \\
\hline ROA t-1 & -.12 & $-.22 *$ & $-.22 *$ & -.12 & $-.24 *$ & -.19 & -.10 & $-.19 *$ & $-.20 *$ \\
\hline Exit proportion t0 & $5.07 * *$ & $4.71 *$ & -1.39 & $4.62 * *$ & $4.55^{*}$ & -2.38 & $4.74 * *$ & $5.71 *$ & -1.33 \\
\hline Entry proportion t0 & -1.00 & -.90 & 2.40 & $-2.36^{*}$ & -.1 .50 & 1.23 & -.87 & -.65 & 2.32 \\
\hline Change in org. tenure & & & & -.05 & -.09 & -.05 & & & \\
\hline \multicolumn{10}{|l|}{ homogeneity during t0 } \\
\hline Change in age & & & & & & & -.16 & -.18 & -.01 \\
\hline \multicolumn{10}{|l|}{ homogeneity during t0 } \\
\hline Wald Chi2 & $15.02 * *$ & $11.96^{*}$ & 8.11 & $13.88 *$ & $13.31 *$ & 6.20 & 10.61 & 11.56 & 6.92 \\
\hline $\mathrm{R}^{2}$ overall & 0.04 & 0.04 & 0.03 & 0.04 & 0.05 & 0.03 & 0.03 & 0.04 & 0.03 \\
\hline
\end{tabular}

\footnotetext{
$* \mathrm{p}<.05, * * \mathrm{p}<.01, * * * \mathrm{p}<.001$
} 

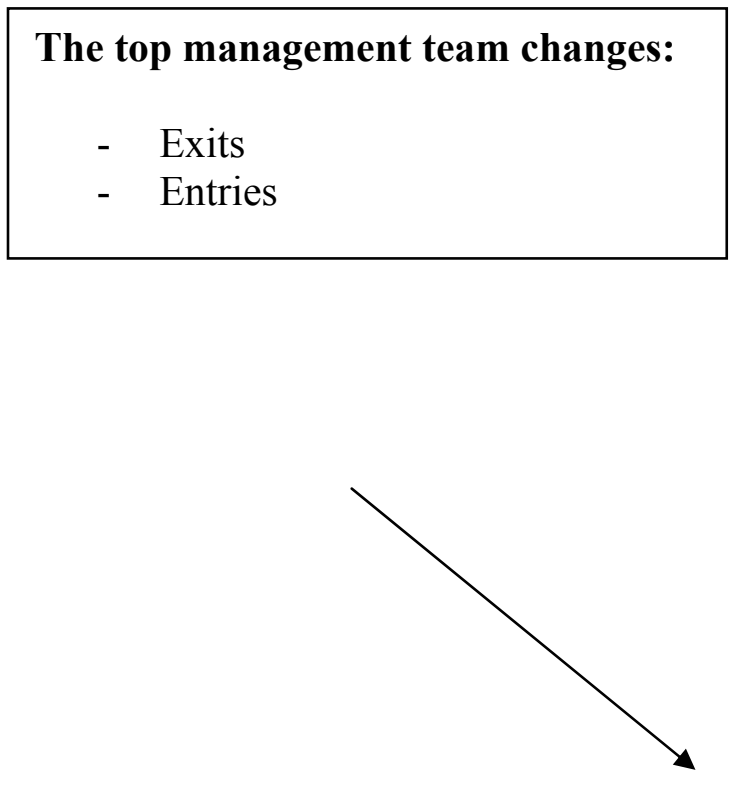

H1
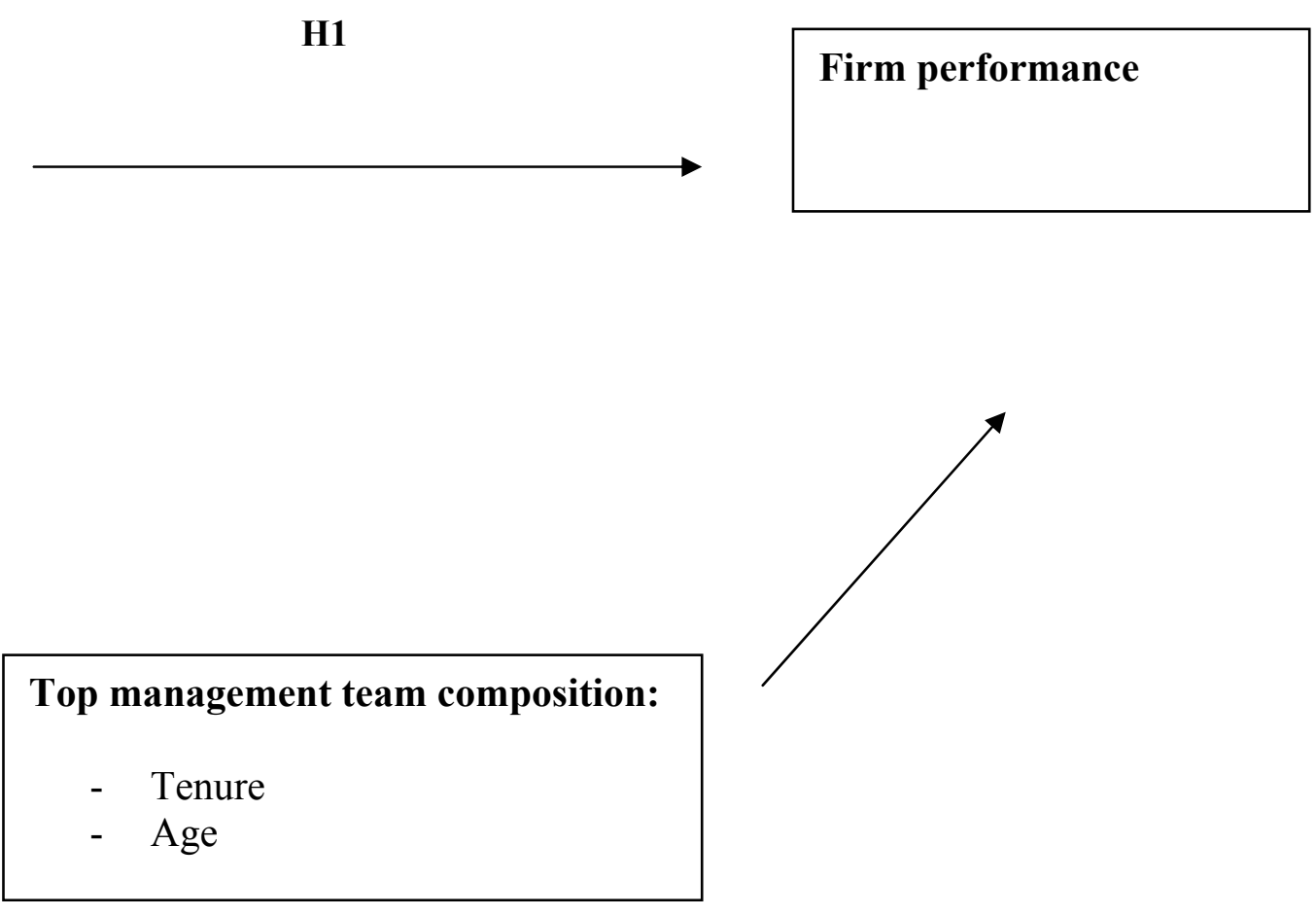

H2 \& H3

Figure 1: Hypotheses and research model 